\title{
TRABAJOS DE VERANO: LA FECH CONSTRUYE POR LIBERAR A CHILE ${ }^{1}$
}

\section{Revista Claridad}

Este número de Claridad apareció a dos meses del triunfo de la Unidad Popular y destaca por reforzar el compromiso de los estudiantes con el "compañero presidente" y el programa de la Unidad Popular, convocando a participar de los trabajos voluntarios, que consistían en poner a disposición de forma gratuita y solidaria todas las capacidades estudiantiles en las áreas de la salud, la construcción, la educación y el ámbito agropecuario.

La selección corresponde a una crónica sobre lo realizado por las y los estudiantes de la universidad en la Población La Faena, de la comuna de Ñuñoa, en los Trabajos de Verano de 1971, los que contaron con un amplio respaldo en organizaciones sociales, políticas y gubernamentales juveniles. Dirigía la revista Lily Corvalán.

1. Claridad (1970, diciembre). Federación de Estudiantes de la Universidad de Chile, pp. 4-5. Disponible en: http:/ /www.memoriachilena.gob.cl/602/w3-article-546422.html 


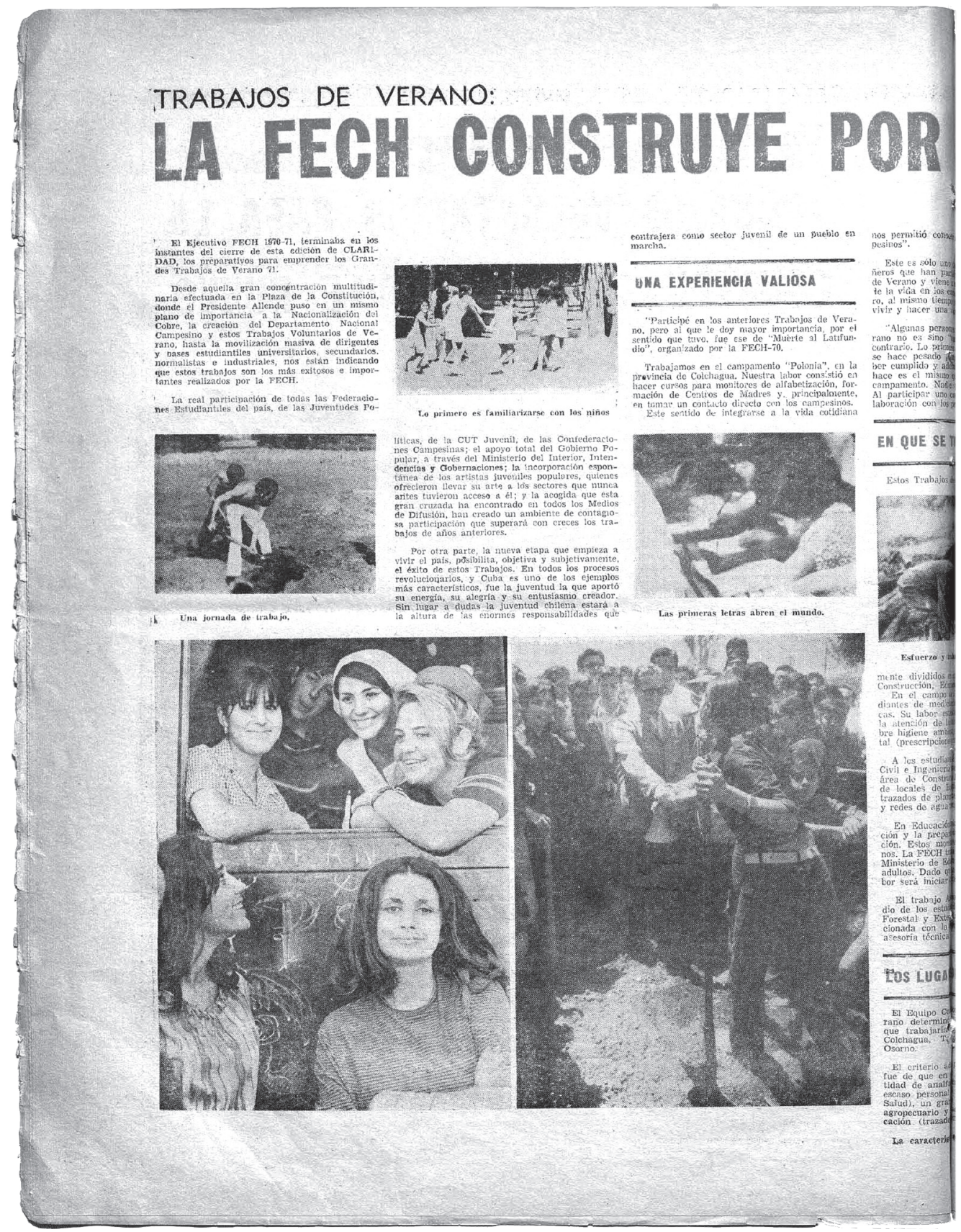




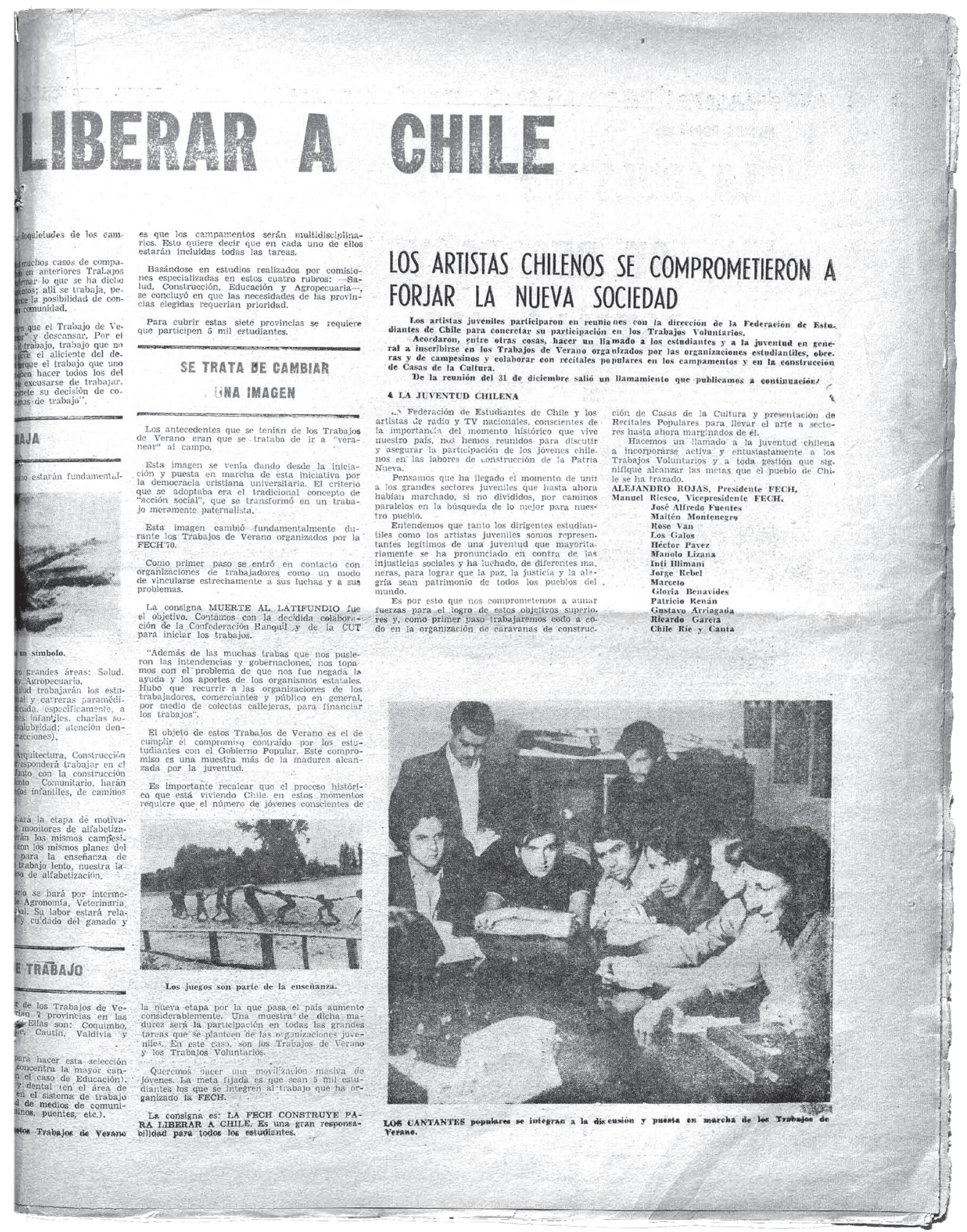

